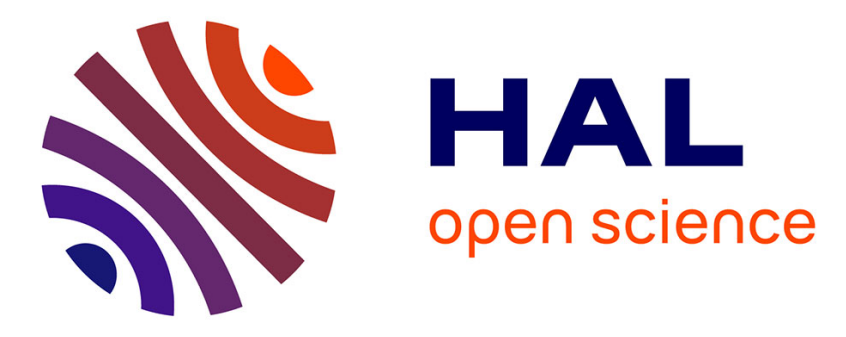

\title{
Implementing isolation perimeters around genetically modified maize fields
}

Yann Devos, Dirk Reheul, Olivier Thas, Eva M. de Clercq, Mathias Cougnon, Karl Cordemans

\section{- To cite this version:}

Yann Devos, Dirk Reheul, Olivier Thas, Eva M. de Clercq, Mathias Cougnon, et al.. Implementing isolation perimeters around genetically modified maize fields. Agronomy for Sustainable Development, 2007, 27 (3), pp.155-165. hal-00886386

\section{HAL Id: hal-00886386 https://hal.science/hal-00886386}

Submitted on 1 Jan 2007

HAL is a multi-disciplinary open access archive for the deposit and dissemination of scientific research documents, whether they are published or not. The documents may come from teaching and research institutions in France or abroad, or from public or private research centers.
L'archive ouverte pluridisciplinaire HAL, est destinée au dépôt et à la diffusion de documents scientifiques de niveau recherche, publiés ou non, émanant des établissements d'enseignement et de recherche français ou étrangers, des laboratoires publics ou privés. 


\title{
Implementing isolation perimeters around genetically modified maize fields
}

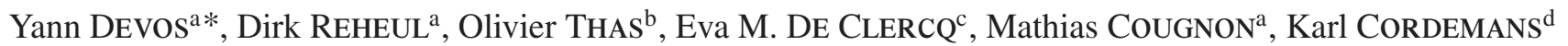 \\ ${ }^{a}$ Department of Plant Production, Faculty of Bioscience Engineering, Ghent University, Coupure Links 653, 9000 Ghent, Belgium \\ ${ }^{\mathrm{b}}$ Department of Applied Mathematics, Biometrics and Process Control, Faculty of Bioscience Engineering, Ghent University, Coupure Links 653,9000 Ghent, \\ Belgium \\ ${ }^{\mathrm{c}}$ Department of Forest and Water Management, Faculty of Bioscience Engineering, Ghent University, Coupure Links 653, 9000 Ghent, Belgium \\ ${ }^{\mathrm{d}}$ Department of Rural Development, Flemish Land Agency, Gulden Vlieslaan 72, 1060 Brussels, Belgium
}

(Accepted 16 January 2007)

\begin{abstract}
Due to the growing cultivation area of genetically modified (GM) maize and the rising number of GM maize varieties commercially available to European farmers, the co-existence between GM and non-GM maize is becoming a burning issue in some European regions. Hence, Member States are imposing or discussing specific co-existence measures to keep the adventitious presence of GM material in nonGM produces below the established labelling threshold. As maize is a cross-pollinated crop that uses wind for the dispersal of its pollen, on-farm co-existence measures may rely on the spatial isolation of GM and non-GM maize fields. In this study, we developed an approach that combines geographic information system (GIS) datasets with Monte Carlo simulations to assess the feasibility of implementing isolation perimeters around GM maize fields, since its practical implementation is rarely addressed in the co-existence debate. More specifically, five scenarios differing in shares and spatial distributions of GM maize were tested for various isolation perimeters in two agricultural areas in Flanders (Belgium). The GIS analyses emphasised the small size of maize fields and their scattered distribution throughout the cropped area. The feasibility of implementing isolation perimeters was largely affected by the (GM) maize share, the spatial distribution of GM maize, and the width of isolation perimeters. The higher the (GM) maize share and the wider the isolation perimeter, the higher the proportions of farmers with non-GM maize fields occurring within the implemented isolation perimeter. Compared with randomly distributed GM maize fields, the clustering of GM maize fields on a larger scale and at the farm level increased the feasibility of implementing isolation perimeters. The approach developed proved to be a valuable tool to quantify the feasibility of implementing isolation perimeters under real agricultural conditions.
\end{abstract}

adventitious mixing / co-existence / cross-fertilisation / genetically modified crops / geographic information system / isolation perimeters / pollen flow / regional variation / simulations

\section{INTRODUCTION}

Since 1996, the worldwide cultivation area of genetically modified (GM) maize has kept increasing to attain 21.2 million ha in 2005, with the highest share being grown in the United States (ca. 80\%). In the European Union (EU), GM maize was predominantly planted commercially in Spain on a modest area of approximately $55088 \mathrm{ha}$. With the registration of eleven Spanish and six French transgenic MON810 varieties in the common EU catalogue of varieties of agricultural plant species on 17 September 2004, the area planted with these maize hybrids increased in France, Germany and Spain, and their commercial cultivation expanded to the Czech Republic and Portugal in 2005. The registration of other, more regionally adapted MON810 hybrids in the German, Spanish and common EU catalogue soon followed. These events may further increase the adoption of the transgenic insectresistant hybrids, especially in regions where the European and/or Mediterranean corn borer are pests (Tab. I).

* Corresponding author: Yann.Devos@UGent.be
Due to the evolutions mentioned, ensuring the co-existence between maize cropping systems is becoming a burning issue in some European regions. Since maize is a cross-pollinated crop relying on wind for the dispersal of its pollen, pollen flow between neighbouring maize fields is one of the potential on-farm sources of adventitious mixing (Devos et al., 2005; Flannery et al., 2005; Sanvido et al., 2005; Bannert, 2006; Van De Wiel and Lotz, 2006). Given the difficulty of keeping transgenes on a leash (Marvier and Van Acker, 2005; Demeke et al., 2006), tolerance thresholds were established for the unintentional or technically unavoidable presence of GM material in non-GM products in the EU. More specifically, a tolerance threshold of $0.9 \%$ applies for food and feed (EC, 2003b), whilst no threshold is officially in place for seeds and organic production yet (Devos et al., accepted). Tolerance thresholds refer to maximum impurity levels for GM content under which co-mingled products do not have to be labelled as consisting of, containing or being produced from a genetically modified organism. In the co-existence debate, these thresholds play a crucial role because the potential incurred socio-economic harm resulting from adventitious mixing will only be actionable if a certain threshold is exceeded. 
Table I. Numbers of GM maize varieties registered in or withdrawn from national catalogues and/or the common EU catalogue of varieties of agricultural plant species (Var), and acreages cropped with GM maize events in the EU (Acr) (data adapted from personal communications of Bartsch, Carvalho, Cerovska, Fresno Ruiz, Grevet, Hervieu, Köller, Roda Ghisleri and Tencalla, and from the consultation of national and the common EU catalogue(s) up to January 2007).

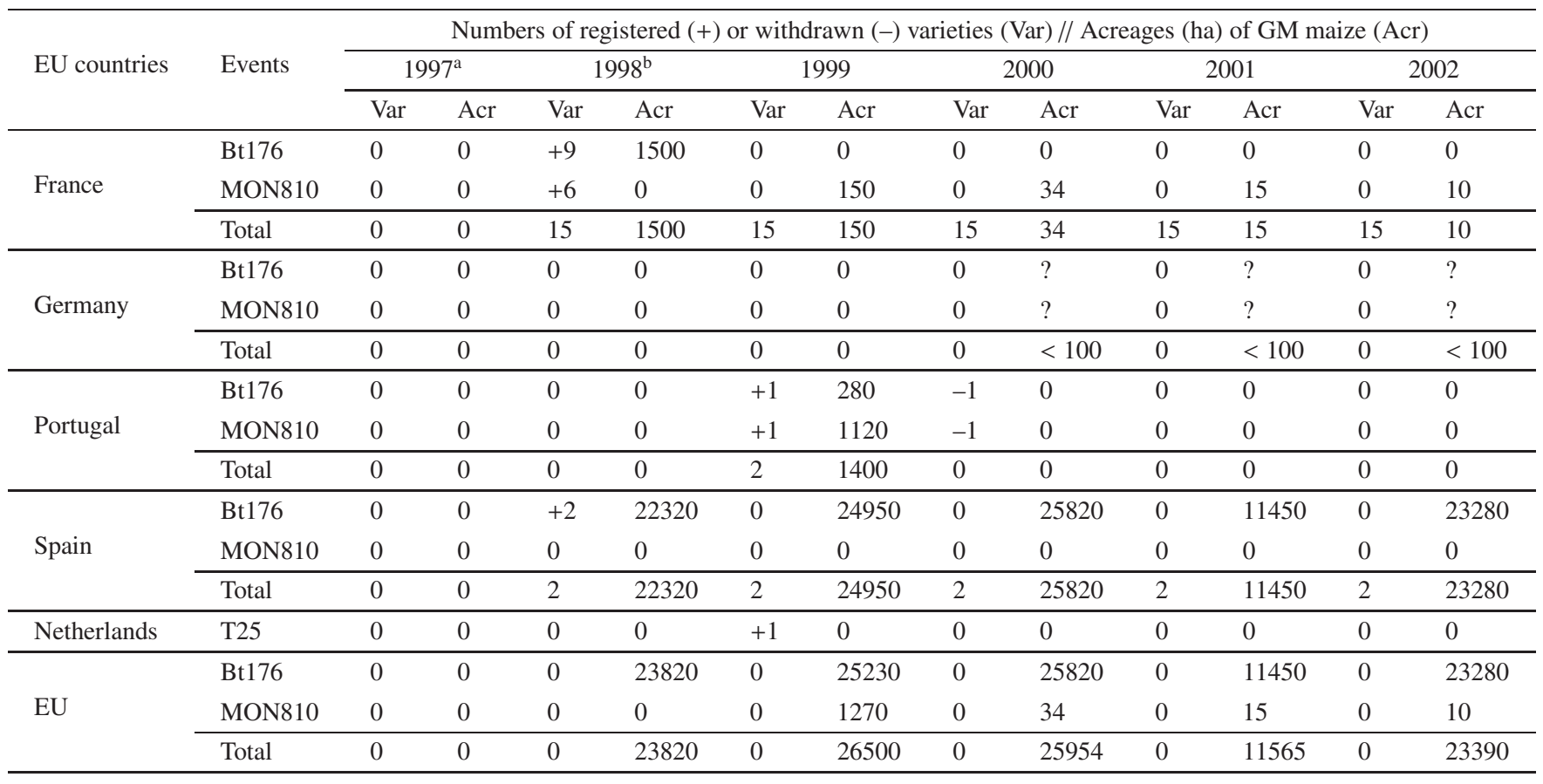

\begin{tabular}{|c|c|c|c|c|c|c|c|c|c|}
\hline \multirow{3}{*}{ EU countries } & \multirow{3}{*}{ Events } & \multicolumn{8}{|c|}{ Numbers of registered (+) or withdrawn (-) varieties (Var) // Acreages (ha) of GM maize (Acr) } \\
\hline & & \multicolumn{2}{|c|}{2003} & \multicolumn{2}{|c|}{2004} & \multicolumn{2}{|c|}{2005} & \multicolumn{2}{|c|}{2006} \\
\hline & & Var & Acr & Var & Acr & Var & Acr & Var & Acr \\
\hline Czech Republic & MON810 & 0 & 0 & 0 & 0 & 0 & 270 & 0 & 1290 \\
\hline \multirow{3}{*}{ France } & Bt176 & 0 & 0 & 0 & 0 & 0 & 0 & 0 & 0 \\
\hline & MON810 & 0 & 17 & 0 & 15 & 0 & 493 & 0 & 5028 \\
\hline & Total & 15 & 17 & 15 & 15 & 15 & 493 & 15 & 5028 \\
\hline \multirow{3}{*}{ Germany } & Bt176 & 0 & $?$ & 0 & $?$ & 0 & 0 & 0 & 0 \\
\hline & MON810 & 0 & $?$ & 0 & $?$ & +3 & 340 & +2 & 954 \\
\hline & Total & 0 & $<100$ & 0 & $<100$ & 3 & 340 & 5 & 954 \\
\hline \multirow{3}{*}{ Portugal } & Bt176 & 0 & 0 & 0 & 0 & 0 & 0 & 0 & 0 \\
\hline & MON810 & 0 & 0 & 0 & 0 & 0 & 760 & 0 & 1254 \\
\hline & Total & 0 & 0 & 0 & 0 & 0 & 760 & 0 & 1254 \\
\hline Slovakia & MON810 & 0 & 0 & 0 & 0 & 0 & 0 & 0 & $<30$ \\
\hline \multirow{3}{*}{ Spain } & Bt176 & +1 & 26090 & $+2,-1$ & 21810 & -4 & 0 & 0 & 0 \\
\hline & MON810 & +4 & 6070 & +7 & 36410 & +14 & 53225 & +11 & 53667 \\
\hline & Total & 7 & 32160 & 15 & 58220 & 25 & 53225 & 36 & 53667 \\
\hline \multirow{3}{*}{ Netherlands } & $\mathrm{T} 25$ & 0 & 0 & 0 & 0 & 0 & 0 & 0 & 0 \\
\hline & MON810 & 0 & 0 & 0 & 0 & 0 & 0 & 0 & $<10$ \\
\hline & Total & 0 & 0 & 0 & 0 & 0 & 0 & 0 & $<10$ \\
\hline \multirow{3}{*}{ EU } & Bt176 & 0 & 26090 & 0 & 21810 & 0 & 0 & 0 & 0 \\
\hline & MON810 & 0 & 6087 & +17 & 36425 & +14 & 55088 & 0 & 62233 \\
\hline & Total & 0 & 32277 & 17 & 58335 & 31 & 55088 & 31 & 62233 \\
\hline
\end{tabular}

a 23/01/1997: EU approval for the event Bt176 pursuant to Directive 90/220/EEC (Commission Decision 97/98/EC).

b 22/04/1998: EU approval for the events MON810 and T25 pursuant to Directive 90/220/EEC (Commission Decisions 98/294/EC and 98/293/EC, respectively). 
Moreover, the thresholds define the required level of containment (Schiemann, 2003).

To keep the adventitious GM content below labelling thresholds in the harvests of neighbouring non-GM maize fields, the guidelines on co-existence of the European Commission (EC) propose the use of various on-farm measures such as isolation perimeters, pollen barriers, crop varieties with different sowing and flowering times, and the clustering of fields with GM crops in production areas (EC, 2003a). Due to the leptokurtic distribution of cross-fertilisation levels over distance from the pollen source, isolating GM maize fields from non-GM ones is a robust strategy to reduce the extent of out-crossing. However, defining the appropriate isolation perimeter width is complicated: various biological, physical, experimental and analytical factors with varying levels of importance play a role in the study of cross-fertilisation in maize (Devos et al., 2005). To take the factors that are relevant for co-existence into account, recent empirical crossfertilisation studies mimic worst-case commercial on-farm situations (Halsey et al., 2005; Della Porta et al., 2006; Goggi et al., 2006; Pla et al., 2006; Weber et al., 2007; Weekes et al., 2007). In Spain, out-crossing studies are even performed in real agricultural situations of co-existence. Fields are planted with different maize cultivars with different sowing or flowering dates, and mixed with other crops and barriers (Messeguer et al., 2006). Study approaches also rely on vertical gene flow modelling at the landscape level to estimate the adventitious GM content in the harvests of neighbouring non-GM maize fields (Messéan et al., 2006). Currently, national and/or local authorities, empowered to develop legal frames coping with co-existence in the EU, are implementing or discussing isolation perimeters lying between 15 and $800 \mathrm{~m}$ (EC, 2006).

Like isolation perimeters, pollen barriers effectively reduce out-crossing between neighbouring maize fields. After a maize pollen barrier of 10-20 m, almost none of the remaining maize contains more than $0.9 \%$ GM material (Gustafson et al., 2006; Messéan et al., 2006; Messeguer et al., 2006; Weber et al., 2007; Weekes et al., 2007). The distance between the inner parts of maize fields increases when the outer parts function as a barrier. Moreover, a maize barrier introduces competing pollen and/or may serve as a physical barrier to air and consequently pollen flow. As such, a maize barrier reduces crossfertilisation much more effectively than an isolation perimeter of bare ground of the same width (Della Porta et al., 2006; Pla et al., 2006). In recipient fields, the margins closest to the pollen donor could be harvested separately, and be discarded or be classified as 'GM maize' when the GM content exceeds the tolerance threshold.

Temporally isolating GM maize fields from non-GM ones is another valuable strategy. A difference in sowing dates may result in a difference in flowering times, hence limiting outcrossing. This strategy is only realistic in Mediterranean regions where the postponement of the sowing will not induce yield penalties (Della Porta et al., 2006; Messeguer et al., 2006). In Germany, Weber et al. (2007) could not avoid overlapping flowering periods by choosing different sowing dates or varieties differing in development. Finally, the EC guidelines recommend the clustering of GM maize fields, because it may favour the management of co-existence (Messéan et al., 2006).

To test the feasibility of implementing isolation perimeters, we developed an approach that combines Geographic Information System (GIS) datasets with Monte Carlo simulations. In contrast to previous studies on the same topic (Dolezel et al., 2005; Sanvido et al., 2005; Messéan et al., 2006), our approach allowed the testing of a series of scenarios differing in GM maize shares and spatial distributions (including the clustering of GM maize) under agricultural conditions in Flanders (Belgium). According to the developed scenarios, it was assessed how spatial co-existence measures would affect the freedom of choice of neighbouring farmers to grow non-GM maize on their fields.

\section{MATERIALS AND METHODS}

\subsection{Spatial analyses}

Using the 2004 data of the Belgian Institute for Statistics, two clusters of adjacent Flemish communes with either a high or a low maize share in the cropped area were selected. The two clusters are further identified as HIGH and LOW. A digital map of agricultural fields of the two selected clusters was provided by the Flemish Land Agency (VLM): confidentiality provisions restricted the information of each field to the cultivated crop, the size of the field and its identification number that corresponds to the farmer who uses the field. The digital maps resulted from the digitalisation of middle-scale orthophotos on a scale of 1/12000. Spatial analyses were performed using the GIS software ArcView 3.1. A square of $25 \mathrm{~km}^{2}$ was delimited within the two clusters. Within these squares, the size of each maize field and the shortest distance between maize fields were calculated from edge to edge with a spatial accuracy of approximately $0.25 \mathrm{~m}$. Distances between maize fields were arranged in a distance matrix.

\subsection{Scenarios}

Given that GM maize is not grown commercially in Flanders yet, variable GM maize shares and spatial distributions were simulated in five different scenarios.

- S1: $10 \%$ of the farmers with the largest maize areas grow GM maize on their largest maize field,

- S2: $10 \%$ of the farmers with the largest maize areas grow GM maize on all their maize fields,

- S3: 10, 30, 50 and $70 \%$ of the maize fields are planted randomly with GM maize,

- S4: 10 and 30\% of the maize fields are clustered and planted with GM maize,

- S5: $10 \%$ of the farmers, who are selected randomly, grow GM maize on all their maize fields.

Scenarios S1 and S2 are expected to correspond to potential developments in a take-off situation of GM maize plantings. The first GM maize growers will probably be the farmers with the largest maize areas, since they will be able to allocate their 

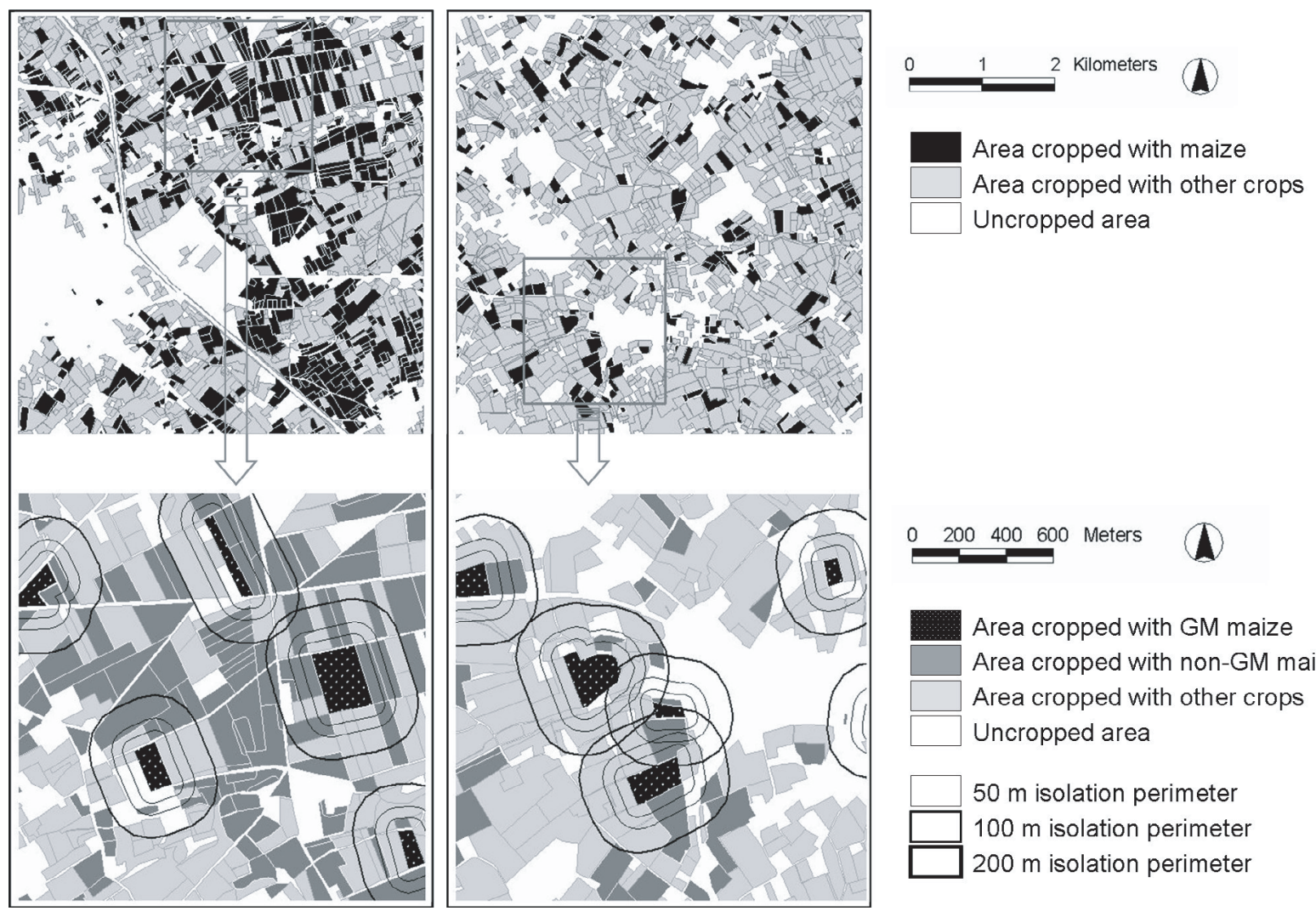

0200400600 Meters

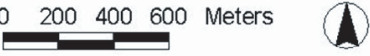

Figure 1. Maps of the selected squares of $25 \mathrm{~km}^{2}$ in HIGH (left) and LOW (right). On top: share of maize fields. Below: concentrically implemented isolation perimeters of 50,100 and $200 \mathrm{~m}$ around some fields planted with GM maize. Pictures adapted from the VLM.

co-existence costs over a large maize area. The random scenario S3 was used as a baseline against which the effect of clustering of GM maize fields was compared. Two different clustering approaches were tested. The selected fields being planted to GM maize were grouped into one cluster per square in S4. Scenarios S2 and S5 were used as models for on-farm clustering: the selected farmers function as islands of on-farm clustered GM maize fields.

The feasibility of implementing various isolation perimeters was assessed in each scenario. Isolation perimeters of $10,25,50,75,100,150,200$ and $300 \mathrm{~m}$ were chosen based on the scientific literature, and on the legal proposals of some neighbouring Member States. According to the European Commission's report on the implementation of national co-existence measures (EC, 2006), most national/regional authorities (including Flanders) are in favour of requesting an isolation perimeter of $200 \mathrm{~m}$ between GM and non-GM maize fields. Based on recent reviews of the scientific literature on pollen flow and cross-fertilisation in maize (Devos et al., 2005; Sanvido et al., 2005; Van De Wiel and Lotz, 2006) and on vertical gene flow modelling at the landscape level (Messéan et al., 2006), it was concluded that isolation perimeters ranging between 10 and $50 \mathrm{~m}$ - depending on field characteristics, crop types, and differences in sowing and flowering times would be sufficient to keep the adventitious GM content resulting from cross-fertilisation below the $0.9 \%$ threshold. Iso- lation perimeters are implemented concentrically around the GM maize fields and refer to the area inside the boundary, including the boundary line (Fig. 1).

\subsection{Calculations and statistical analyses}

Scenarios S1 and S2 are deterministic: farmers and their corresponding maize fields to be planted with GM maize were identified clearly by the scenarios. Using the distance matrix, it was calculated how many non-GM maize fields and farmers with at least one non-GM maize field were present within the chosen isolation perimeters.

In scenarios S3, S4 and S5, maize fields to be planted with GM maize or farmers that cultivate GM maize on their maize fields were selected randomly by a Monte Carlo analysis with 10000 simulation runs, identifying 10000 different combinations of GM maize field allocation. For each simulation run, it was calculated how many and which fields fell within a chosen perimeter. After 10000 simulation runs, the relative frequency that zero, one, two or more non-GM maize fields fell within the perimeters was calculated. Using the relative frequencies of occurrence of non-GM maize fields as the weight for each number of non-GM maize fields, a weighted average of non-GM maize fields occurring within an isolation perimeter was calculated. An identical approach was followed for farmers that have at least one non-GM maize field within the perimeters. 
Table II. Characteristics of the selected squares of $25 \mathrm{~km}^{2}$ in LOW and HIGH in 2004. Between brackets: means \pm standard deviations of 2004, 2005 and 2006.

\begin{tabular}{|c|c|c|c|c|c|c|c|c|c|}
\hline $\begin{array}{l}\text { Squares } \\
\text { (2500 ha) }\end{array}$ & $\begin{array}{l}\text { Cropped } \\
\text { area (ha) }\end{array}$ & $\begin{array}{l}\text { Share of } \\
\text { cropped } \\
\text { area in the } \\
\text { square }(\%)\end{array}$ & $\begin{array}{l}\text { Area cropped } \\
\text { with maize } \\
\text { (ha) }\end{array}$ & $\begin{array}{l}\text { Share of } \\
\text { maize in } \\
\text { cropped } \\
\text { area }(\%)\end{array}$ & $\begin{array}{l}\text { Share of } \\
\text { maize in } \\
\text { square } \\
(\%)\end{array}$ & $\begin{array}{l}\text { Number of } \\
\text { maize } \\
\text { fields }\end{array}$ & $\begin{array}{l}\text { Average size } \\
\text { of maize } \\
\text { fields (ha) }\end{array}$ & $\begin{array}{l}\text { Number } \\
\text { of farmers }\end{array}$ & $\begin{array}{l}\text { Number of } \\
\text { maize fields } \\
\text { per farmer }\end{array}$ \\
\hline HIGH & $\begin{array}{l}1631 \\
(1644 \pm 11)\end{array}$ & $\begin{array}{l}65 \\
(66 \pm 1)\end{array}$ & $\begin{array}{l}732 \\
(751 \pm 24)\end{array}$ & $\begin{array}{l}45 \\
(46 \pm 1)\end{array}$ & $\begin{array}{l}29 \\
(30 \pm 1)\end{array}$ & $\begin{array}{l}625 \\
(626 \pm 19)\end{array}$ & $\begin{array}{l}1.2 \\
(1.2 \pm 0.0)\end{array}$ & $\begin{array}{l}142 \\
(143 \pm 2)\end{array}$ & $\begin{array}{l}4.4 \\
(4.4 \pm 0.2)\end{array}$ \\
\hline
\end{tabular}

In $\mathrm{S} 4$, each simulation run consisted of randomly selecting the first maize field to be planted with GM maize in the square and, subsequently, of selecting the closest neighbouring maize fields, whilst $10 \%$ of the maize farmers were selected randomly in S5. Calculations were done as given in S3. Due to the large number of simulation runs, the maximal standard deviation $(\mathrm{SD})$ on the estimated probabilities $(\mathrm{P})$ was $0.5 \%[\mathrm{SD}(\mathrm{P})=\operatorname{sqrt}(\mathrm{P}(1-\mathrm{P}) / 10000)]$.

Similarly, the proportions of non-GM maize fields in the square (and their corresponding farmers) falling within the perimeters were calculated in each simulation run. Fields (and corresponding farmers) occurring within the perimeters of several GM maize fields were counted only once. All calculations were performed in the statistical R 2.3.1 software.

Numbers and proportions of non-GM maize fields and farmers with at least one non-GM maize field occurring within an isolation perimeter (Y) were regressed on the isolation perimeter widths $(\mathrm{X})$ using the cubic regression model $(\mathrm{Y}=$ $\left.\mathrm{b}_{0}+\mathrm{b}_{1} \mathrm{X}+\mathrm{b}_{2} \mathrm{X}^{2}+\mathrm{b}_{3} \mathrm{X}^{3}\right)$. Data were fitted to the model via a nonlinear regression procedure, provided with SPSS14. Regression formulas allow the interpolation of the numbers and proportions of non-GM maize fields and involved farmers within the range of the tested isolation perimeters.

\section{RESULTS AND DISCUSSION}

\subsection{Characteristics of the selected squares}

The area cropped with maize varied from $11 \%$ in LOW to $29 \%$ in HIGH. Expressed on the cropped area within these squares, the maize shares varied from $15 \%$ in LOW to $45 \%$ in HIGH. In HIGH, each farmer had on average 4.4 maize fields, compared with 2.4 in LOW (Tab. II).

The size of maize fields in HIGH and LOW was on average 1.2 ha, with an unequally distributed leptokurtic pattern. Most fields $(80 \%)$ were smaller than 2 ha, whilst larger fields ( $>4$ ha) were rare $(3 \%)$. Fields with a size ranging between 0.5 and 0.9 ha were the most abundant $(31 \%)$.

The data used refer to the year 2004. These data are very representative for maize growing in the selected squares as they are very close to the means of the three most recent years (Tab. II).

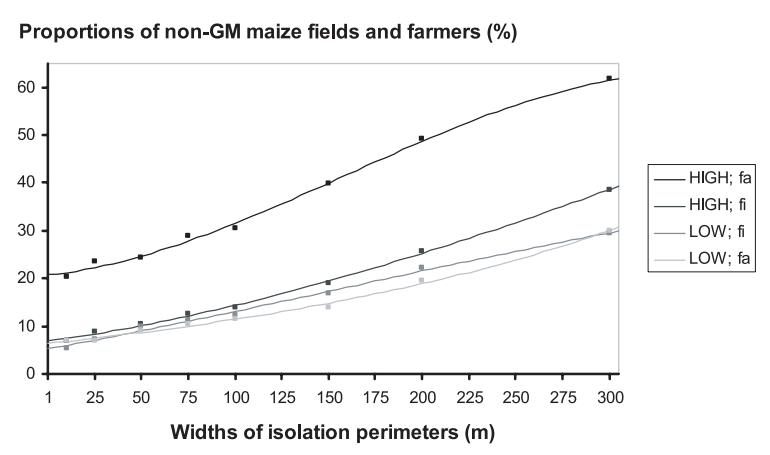

Figure 2. Proportions of non-GM maize fields (fi) and farmers with at least one non-GM maize field (fa) occurring within an isolation perimeter, in relation to the width of isolation perimeters. Scenario $\mathrm{S} 1$; situation in $\mathrm{HIGH}$ and LOW. Regression formulas are given in Table VII.

\subsection{Scenario S1: $10 \%$ of the farmers with the largest maize areas grow GM maize on their largest maize field}

Both the proportions of non-GM maize fields and farmers that have at least one non-GM maize field occurring within an implemented isolation perimeter increased with increasing isolation perimeter widths (Fig. 2). With the implementation of an isolation perimeter of $10 \mathrm{~m}, 6.9 \%$ of all non-GM maize fields fell within the isolation perimeter in HIGH. Increasing the isolation perimeter width to 50 and $200 \mathrm{~m}$ increased the proportions of non-GM maize fields to 10.3 and $25.7 \%$, respectively. The proportions of non-GM maize fields occurring within the isolation perimeters of 10,50 and $200 \mathrm{~m}$ involved, respectively, 20.3, 24.2 and $49.2 \%$ of all non-GM maize farmers.

Table VII gives additional data.

As was expected, the higher the maize share in a square, the higher the proportions of non-GM maize fields that were present within the perimeters, whatever the imposed isolation perimeter was, and consequently the higher the proportions of farmers that were involved.

\subsection{Scenario S2: $10 \%$ of the farmers with the largest maize areas grow GM maize on all their maize fields}

Compared with S1, the percentage of maize fields being planted to GM maize was approximately fourteen times higher 
Table III. Spatial characteristics corresponding to the selected scenarios.

\begin{tabular}{llll}
\hline Scenarios & Squares & $\begin{array}{l}\text { Percentages of maize } \\
\text { fields planted to GM } \\
\text { maize }\end{array}$ & GM maize shares (\%) \\
\hline S1 & HIGH & 2 & 11 \\
& LOW & 4 & 13 \\
S2 & HIGH & 28 & 40 \\
& LOW & 26 & 31 \\
S3 & HIGH & $10,30,50,70$ & $10,31,51,72$ \\
& LOW & $10,30,50,70$ & $11,32,53,74$ \\
S4 & HIGH & 10,30 & 10,31 \\
& LOW & 10,30 & 11,32 \\
S5 & HIGH & 10 & 10 \\
& LOW & 10 & 11 \\
\hline
\end{tabular}

in HIGH and eight times higher in LOW (Tab. III). This increase in GM maize fields and the corresponding GM maize share resulted in high proportions of non-GM maize fields and farmers within the isolation perimeters. Given that $10 \%$ of the farmers with the largest maize areas grow GM maize on all their maize fields, and given an isolation perimeter of $10 \mathrm{~m}$, $43.2 \%$ of all non-GM maize fields in HIGH fell within the perimeter. Increasing the isolation perimeter from $10 \mathrm{~m}$ to 50 and $200 \mathrm{~m}$ increased the proportions of non-GM maize fields occurring within the isolation perimeter to 52.8 and $85.8 \%$, respectively. The proportions of non-GM maize fields involved 68.0, 76.6 and $94.5 \%$ of all non-GM maize farmers (Fig. 3).

\subsection{Scenario S3: $10,30,50$ and $70 \%$ of the maize fields are planted randomly with GM maize}

The lower the percentages of maize fields planted to GM maize and the wider the isolation perimeter, the higher the probabilities that many non-GM maize fields and corresponding farmers fell within the perimeter, whatever the width of the isolation perimeter (Tab. IV).

In the case where $10 \%$ of the maize fields were planted with GM maize, on average, 2.3, 3.4 and 10.5 non-GM maize fields were present within the isolation perimeter of 10,50 and $200 \mathrm{~m}$ in HIGH, respectively. The numbers of non-GM maize fields involved 2.0, 2.8 and 7.1 non-GM maize farmers, respectively. If $70 \%$ of the maize fields were cropped to GM maize, the numbers of non-GM maize fields lying within the 10,50 and $200 \mathrm{~m}$ isolation perimeter decreased to $0.8,1.1$ and 3.5 (Fig. 4). These numbers corresponded to $0.7,1.1$ and 3.0 non-GM maize farmers (Tab. VII).

Although the percentages of maize fields cropped with GM maize were quite similar (Tab. III), the observed proportions of non-GM maize fields were higher than those obtained in S2. If the percentage of maize fields being randomly planted to GM maize was $10 \%$, the proportions of non-GM maize fields falling within the 10,50 and $200 \mathrm{~m}$ isolation perime-

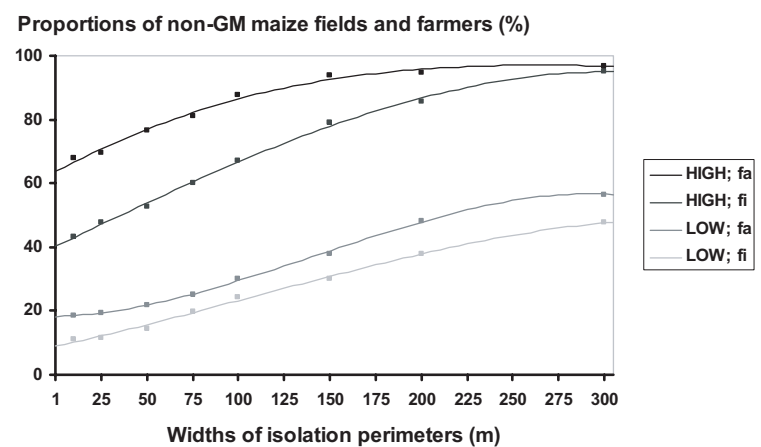

Figure 3. Proportions of non-GM maize fields (fi) and farmers with at least one non-GM maize field (fa) within an isolation perimeter, in relation to the width of isolation perimeters. Scenario S2; situation in HIGH and LOW. Regression formulas are provided in Table VII.

ters were $22.6 \pm 1.8,31.3 \pm 2.2$ and $65.8 \pm 3.3 \%$, involving $38.7 \pm 4.8,47.5 \pm 4.8$ and $77.0 \pm 4.4 \%$ of non-GM maize farmers in $\mathrm{HIGH}$, respectively. Increasing the percentages of maize fields cropped to GM maize to $70 \%$ increased the proportions of non-GM maize fields within the 10,50 and $200 \mathrm{~m}$ isolation perimeters to $81.3 \pm 2.7,89.3 \pm 2.2$ and $98.4 \pm 0.9 \%$, respectively (Fig. 5). The proportions of non-GM maize fields involved $81.8 \pm 9.1,86.5 \pm 8.0$ and $98.9 \pm 2.7 \%$ of non-GM maize farmers (Tab. VII).

\subsection{Scenario S4: 10 and $30 \%$ of the maize fields are clustered and planted to GM maize}

Compared with a random distribution (Tab. IV), the clustering of GM maize fields (Tab. V) clearly reduced the probabilities that non-GM maize fields and corresponding farmers fall within imposed isolation perimeters.

The clustering of GM maize fields reduced the numbers of non-GM maize fields occurring within the isolation perimeter by at least a fourth, compared with a similar situation where GM maize was randomly allocated. Numbers of farmers with at least one non-GM maize field occurring within the isolation perimeter were reduced by at least a third. In the case where $10 \%$ of the maize fields were clustered and planted with GM maize, $0.3,0.5$ and 2.1 non-GM maize fields occurred within the 10,50 and $200 \mathrm{~m}$ isolation perimeters, involving $0.3,0.4$ and 1.6 non-GM maize farmers in HIGH, respectively.

Compared with a situation in which GM maize fields were randomly distributed, the proportions of non-GM maize fields and farmers occurring within isolation perimeters were five to ten times lower when GM maize fields were grouped in one large cluster. If the $10 \%$ GM maize fields were clustered in $\mathrm{HIGH}$ and an isolation perimeter of $10 \mathrm{~m}$ was imposed, $2.4 \pm$ $1.1 \%$ of all non-GM maize fields were present in the isolation perimeters, involving $3.7 \pm 2.3 \%$ of non-GM maize farmers. Increasing the isolation perimeter width from $10 \mathrm{~m}$ to 50 and $200 \mathrm{~m}$ increased the proportions of non-GM maize fields to $3.2 \pm 1.3$ and $7.1 \pm 2.4 \%$, respectively (Fig. 6). The proportions of non-GM maize fields involved $4.8 \pm 2.6$ and $10.7 \pm 4.3 \%$ of all non-GM maize farmers (Tab. VII). 
Table IV. Probabilities (\%) that at least 1, 3 or 5 field(s) of non-GM maize (fi) and farmer(s) (fa) fall within a perimeter of 10,50 and $200 \mathrm{~m}$ of a GM maize field. GM maize is grown at random on 10, 30, 50 and 70\% of the maize fields in HIGH and LOW.

\begin{tabular}{|c|c|c|c|c|c|c|c|c|c|c|}
\hline \multirow[t]{3}{*}{ Squares } & \multirow{3}{*}{$\begin{array}{l}\text { Isolation } \\
\text { perimeters } \\
(\mathrm{m})\end{array}$} & \multirow{3}{*}{$\begin{array}{l}\text { Numbers of } \\
\text { fields or } \\
\text { farmers in the } \\
\text { perimeters }\end{array}$} & \multicolumn{8}{|c|}{ Percentages of maize fields randomly cropped with GM maize } \\
\hline & & & \multicolumn{2}{|c|}{10} & \multicolumn{2}{|c|}{30} & \multicolumn{2}{|c|}{50} & \multicolumn{2}{|c|}{70} \\
\hline & & & fi & fa & fi & fa & fi & fa & fi & fa \\
\hline \multirow{8}{*}{ HIGH } & \multirow[t]{3}{*}{10} & $\geq 1$ & 87.4 & 87.4 & 81.3 & 81.3 & 70.6 & 70.6 & 52.7 & 52.7 \\
\hline & & $\geq 3$ & 40.0 & 31.5 & 26.7 & 20.7 & 14.2 & 10.8 & 4.7 & 3.5 \\
\hline & & $\geq 5$ & 8.9 & 4.9 & 4.6 & 2.2 & 1.6 & 0.7 & 0.3 & 0.1 \\
\hline & \multirow{2}{*}{50} & $\geq 3$ & 62.8 & 54.0 & 48.3 & 40.0 & 29.9 & 23.8 & 11.9 & 8.9 \\
\hline & & $\geq 5$ & 27.0 & 15.6 & 14.9 & 7.8 & 6.2 & 2.7 & 1.2 & 0.4 \\
\hline & \multirow[t]{3}{*}{200} & $\geq 1$ & 98.9 & 98.9 & 98.4 & 98.4 & 97.1 & 97.1 & 92.6 & 92.6 \\
\hline & & $\geq 3$ & 94.7 & 92.4 & 91.5 & 88.4 & 83.9 & 79.3 & 62.2 & 56.2 \\
\hline & & $\geq 5$ & 87.1 & 76.8 & 79.4 & 66.7 & 61.9 & 47.8 & 29.7 & 19.9 \\
\hline \multirow{6}{*}{ LOW } & \multirow[t]{3}{*}{50} & $\geq 1$ & 62.3 & 62.3 & 54.1 & 54.1 & 43.7 & 43.7 & 29.7 & 29.8 \\
\hline & & $\geq 3$ & 10.6 & 7.0 & 6.6 & 4.0 & 3.1 & 1.7 & 0.8 & 0.4 \\
\hline & & $\geq 5$ & 0.8 & 0.0 & 0.2 & 0.0 & 0.0 & 0.0 & 0.0 & 0.0 \\
\hline & \multirow[t]{3}{*}{200} & $\geq 1$ & 94.0 & 94.0 & 88.1 & 88.1 & 79.0 & 79.0 & 62.7 & 62.7 \\
\hline & & $\geq 3$ & 54.9 & 42.7 & 42.7 & 31.4 & 28.1 & 19.8 & 11.7 & 7.8 \\
\hline & & $\geq 5$ & 26.4 & 12.2 & 15.7 & 6.0 & 6.4 & 2.1 & 1.0 & 0.3 \\
\hline
\end{tabular}

Table V. Probabilities (\%) that at least 1, 3 or 5 field(s) of non-GM maize (fi) and farmer(s) (fa) lie within the perimeters of 10,50 and $200 \mathrm{~m}$ of a GM maize field. GM maize is grown in a cluster of 10 and $30 \%$ of the maize fields in HIGH and LOW.

\begin{tabular}{|c|c|c|c|c|c|c|c|c|c|}
\hline \multirow{4}{*}{$\begin{array}{l}\text { Isolation } \\
\text { perimeters } \\
(\mathrm{m})\end{array}$} & \multirow{4}{*}{$\begin{array}{l}\text { Numbers } \\
\text { of fields or } \\
\text { farmers in } \\
\text { the } \\
\text { perimeters }\end{array}$} & \multicolumn{8}{|c|}{$\begin{array}{c}\text { Percentages of maize fields cropped with GM maize and } \\
\text { organised as clusters }\end{array}$} \\
\hline & & \multicolumn{4}{|c|}{ HIGH } & \multicolumn{4}{|c|}{ LOW } \\
\hline & & \multicolumn{2}{|c|}{10} & \multicolumn{2}{|c|}{30} & \multicolumn{2}{|c|}{10} & \multicolumn{2}{|c|}{30} \\
\hline & & fi & fa & fi & $\mathrm{fa}$ & fi & $\mathrm{fa}$ & fi & $\mathrm{fa}$ \\
\hline \multirow[t]{3}{*}{10} & $\geq 1$ & 16.6 & 16.6 & 7.5 & 7.5 & 6.8 & 6.8 & 3.4 & 3.4 \\
\hline & $\geq 3$ & 2.9 & 2.3 & 1.2 & 0.9 & 0.3 & 0.2 & 0.2 & 0.1 \\
\hline & $\geq 5$ & 0.5 & 0.2 & 0.2 & 0.1 & 0.0 & 0.0 & 0.0 & 0.0 \\
\hline \multirow[t]{3}{*}{50} & $\geq 1$ & 22.5 & 22.5 & 10.2 & 10.2 & 9.7 & 9.7 & 4.9 & 4.9 \\
\hline & $\geq 3$ & 6.2 & 4.7 & 2.6 & 1.9 & 0.9 & 0.6 & 0.3 & 0.2 \\
\hline & $\geq 5$ & 1.5 & 0.6 & 0.6 & 0.2 & 0.0 & 0.0 & 0.0 & 0.0 \\
\hline \multirow[t]{3}{*}{200} & $\geq 1$ & 49.9 & 49.8 & 22.8 & 22.9 & 28.7 & 28.7 & 14.8 & 14.8 \\
\hline & $\geq 3$ & 30.2 & 26.8 & 12.9 & 11.2 & 7.8 & 5.3 & 3.4 & 2.3 \\
\hline & $\geq 5$ & 18.7 & 12.9 & 7.5 & 5.0 & 2.1 & 0.6 & 0.8 & 0.3 \\
\hline
\end{tabular}

\subsection{Scenario S5: $10 \%$ of the farmers, who are selected} randomly, grow GM maize on all their maize fields

The observed probabilities were slightly lower than those obtained in S3, but much higher than those seen in S4 (Tab. VI).

2.0, 2.9 and 9.4 non-GM maize fields were present in the 10, 50 and $200 \mathrm{~m}$ isolation perimeters in HIGH, respectively. This involved 1.7, 2.4 and 6.4 non-GM maize farmers (Tab. VII).
With the implementation of an isolation perimeter of $10 \mathrm{~m}$, $17.1 \pm 4.3 \%$ of all non-GM maize fields were present within the isolation perimeters, involving $40.5 \pm 6.7 \%$ of all nonGM maize farmers in HIGH. Increasing the isolation perimeter width from $10 \mathrm{~m}$ to $50 \mathrm{~m}$ and to $200 \mathrm{~m}$ increased the proportions to $22.9 \pm 5.4 \%$ and to $49.3 \pm 8.4 \%$, respectively (Fig. 7). The proportions of non-GM maize fields occurring within the isolation perimeters of 50 and $200 \mathrm{~m}$, respectively, involved 


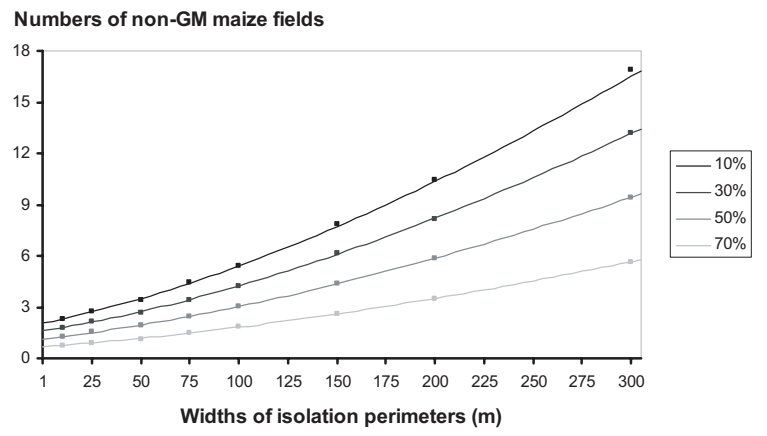

Figure 4. Numbers of non-GM maize fields within an isolation perimeter, related to the width of isolation perimeters. Scenario S3 in HIGH; 10, 30, 50 and $70 \%$ of the maize fields are planted randomly with GM maize. Regression formulas are given in Table VII.

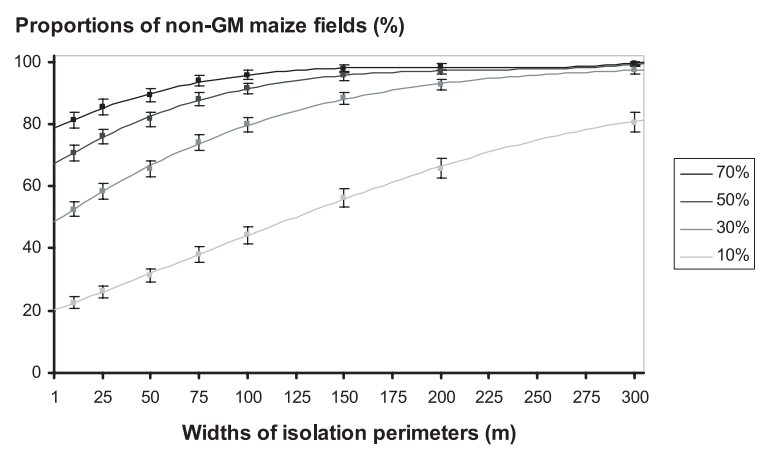

Figure 5. Proportions of non-GM maize fields occurring within an isolation perimeter, related to the width of isolation perimeters. Scenario S3 in HIGH; 10, 30, 50 and $70 \%$ of the maize fields are planted randomly with GM maize. Regression formulas are provided in $\mathrm{Ta}-$ ble VII.

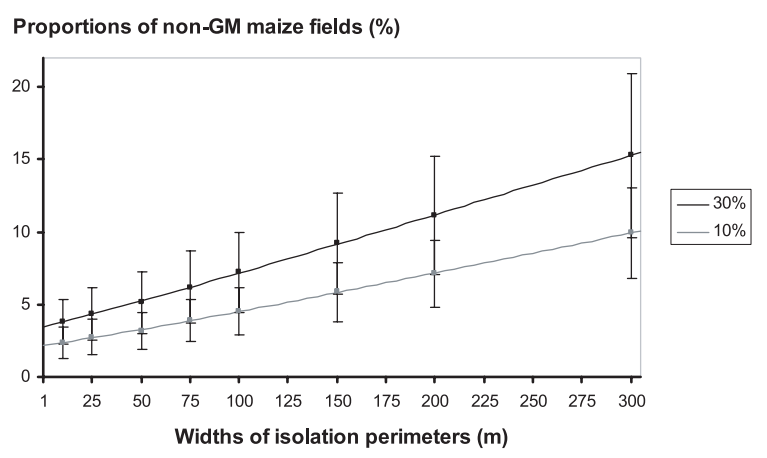

Figure 6. Proportions of non-GM maize fields within an isolation perimeter, in relation to the isolation perimeter widths. Scenario S4 in $\mathrm{HIGH} ; 10$ and $30 \%$ of GM maize fields are clustered. Regression formulas are provided in Table VII.

$47.7 \pm 6.9$ and $72.4 \pm 6.9 \%$ of all non-GM maize farmers. The observed proportions were slightly lower than those seen in S3, but higher than those observed in S4 (Tab. VII).

Although the total area planted with GM maize was similar to that in S1, the fivefold increase in percentage of maize fields planted with GM maize, approximately, doubled the propor-
Table VI. Probabilities (\%) that at least 1, 3 or 5 field(s) of non-GM maize (fi) and farmer(s) (fa) fall within the perimeters of 10, 50 and $200 \mathrm{~m}$ of a GM maize field. $10 \%$ of the farmers grow GM maize on all their maize fields in HIGH and LOW.

\begin{tabular}{|c|c|c|c|c|c|c|c|}
\hline \multirow[t]{3}{*}{ Squares } & \multirow{3}{*}{$\begin{array}{l}\text { Numbers of } \\
\text { fields or farmers } \\
\text { in the perimeters }\end{array}$} & \multicolumn{6}{|c|}{ Isolation perimeters $(\mathrm{m})$} \\
\hline & & \multicolumn{2}{|c|}{10} & \multicolumn{2}{|c|}{50} & \multicolumn{2}{|c|}{200} \\
\hline & & fi & $\mathrm{fa}$ & fi & $\mathrm{fa}$ & fi & $\mathrm{fa}$ \\
\hline \multirow[t]{3}{*}{ HIGH } & $\geq 1$ & 80.3 & 80.3 & 87.6 & 87.5 & 97.8 & 97.8 \\
\hline & $\geq 3$ & 33.2 & 25.9 & 53.4 & 43.2 & 92.7 & 88.3 \\
\hline & $\geq 5$ & 7.4 & 3.4 & 20.8 & 11.4 & 83.6 & 69.1 \\
\hline \multirow[t]{3}{*}{ LOW } & $\geq 1$ & 35.1 & 35.1 & 47.7 & 47.7 & 87.8 & 87.8 \\
\hline & $\geq 3$ & 2.9 & 1.8 & 6.5 & 3.6 & 39.2 & 29.2 \\
\hline & $\geq 5$ & 0.3 & 0.0 & 0.6 & 0.0 & 16.8 & 5.2 \\
\hline
\end{tabular}

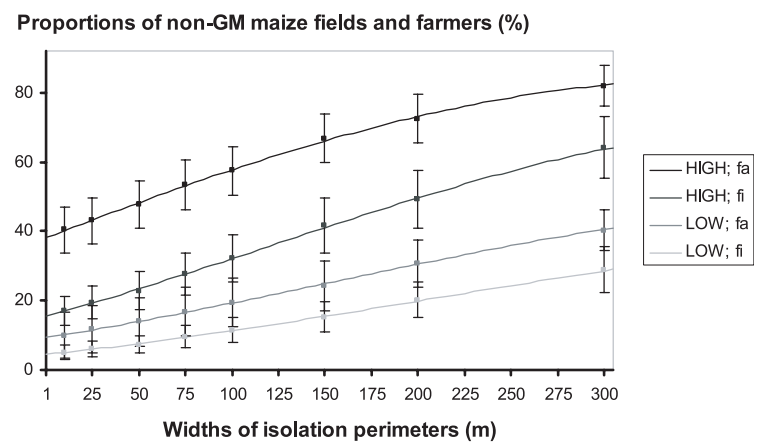

Figure 7. Proportions of non-GM maize fields (fi) and farmers with at least one non-GM maize field (fa) within an isolation perimeter, in relation to the width of isolation perimeters. Scenario S5; situation in HIGH and LOW. Regression formulas are given in Table VII.

tions of non-GM maize fields occurring within the perimeters in $\mathrm{HIGH}$.

\section{CONCLUSION}

The GIS analysis emphasised the small size of maize fields, their scattered distribution throughout the cropped area and the considerable variation in maize shares between the two studied areas. This regional variability largely affects the feasibility of implementing isolation perimeters around GM maize fields. Irrespective of the tested scenario, the proportions of non-GM maize fields and farmers with at least one non-GM maize field occurring within an implemented isolation perimeter were always higher in the region with a high maize share than in the region with a low share, which makes the spatial separation between GM and non-GM maize fields more difficult in areas where maize is abundantly grown.

For a given area or GM maize share, growing this maize in a high number of small fields is less attractive than growing the same area in a small number of large fields, as indicated and quantified by the comparison of scenario S1 with S5.

Our results showed that the proportions of non-GM maize fields and farmers with non-GM maize fields occurring within 
Table VII. Regressions of numbers and proportions of non-GM maize fields $\left(\mathrm{Y}_{f i}\right)$ and farmers with at least one non-GM maize field $\left(\mathrm{Y}_{f a}\right)$ occurring within an isolation perimeter on

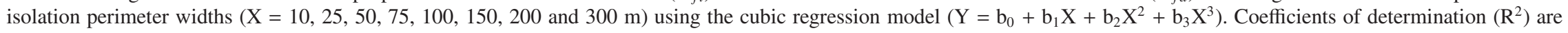
given.

\begin{tabular}{|c|c|c|c|c|c|c|c|c|c|c|c|c|}
\hline \multirow{2}{*}{ Squares } & \multicolumn{6}{|c|}{$\mathrm{Y}=$ numbers of non-GM maize fields or farmers } & \multicolumn{6}{|c|}{$\mathrm{Y}=$ proportions of non-GM maize fields or farmers } \\
\hline & $\mathrm{Y}$ & $\mathrm{b}_{0}$ & $\mathrm{~b}_{1}$ & $\mathrm{~b}_{2}$ & $\mathrm{~b}_{3}$ & $\mathrm{R}^{2}$ & $\mathrm{Y}$ & $\mathrm{b}_{0}$ & $b_{1}$ & $\mathrm{~b}_{2}$ & $\mathrm{~b}_{3}$ & $\mathrm{R}^{2}$ \\
\hline \multicolumn{13}{|c|}{ S1: $10 \%$ of the farmers with the largest maize areas grow GM maize on their largest maize field } \\
\hline \multirow[t]{2}{*}{ HIGH } & & & & & & & $\mathrm{Y}_{f i}$ & 6.81669 & 0.05566 & 0.00021 & $-1.39730 \times 10^{-7}$ & $0.998^{*}$ \\
\hline & & & & & & & $\mathrm{Y}_{f a}$ & 20.69939 & 0.04099 & 0.00085 & $-1.78024 \times 10^{-6}$ & $0.997^{*}$ \\
\hline \multirow[t]{2}{*}{ LOW } & & & & & & & $\mathrm{Y}_{f i}$ & 5.26837 & 0.07060 & $9.30673 \times 10^{-5}$ & $-1.96869 \times 10^{-7}$ & $0.994^{*}$ \\
\hline & & & & & & & $\mathrm{Y}_{f a}$ & 6.34862 & 0.04366 & $5.14765 \times 10^{-5}$ & $2.17895 \times 10^{-7}$ & $0.995^{*}$ \\
\hline \multicolumn{13}{|c|}{ S2: $10 \%$ of the farmers with the largest maize areas grow GM maize on all their maize fields } \\
\hline \multirow[t]{2}{*}{ HIGH } & & & & & & & $\mathrm{Y}_{f i}$ & 40.21047 & 0.27888 & $-5.14822 \times 10^{-5}$ & $-8.98984 \times 10^{-7}$ & $0.998^{*}$ \\
\hline & & & & & & & $\mathrm{Y}_{f a}$ & 63.58355 & 0.31289 & -0.00093 & $8.51274 \times 10^{-7}$ & $0.990^{*}$ \\
\hline \multirow[t]{2}{*}{ LOW } & & & & & & & $\mathrm{Y}_{f i}$ & 8.99494 & 0.12286 & 0.00028 & $-8.66191 \times 10^{-7}$ & $0.996^{*}$ \\
\hline & & & & & & & $\mathrm{Y}_{f a}$ & 18.21904 & 0.01962 & 0.00121 & $-2.82788 \times 10^{-6}$ & $0.999^{*}$ \\
\hline \multicolumn{13}{|c|}{ S3: $10 \%$ of the maize fields are planted randomly with GM maize } \\
\hline \multirow[t]{2}{*}{ HIGH } & $\mathrm{Y}_{f i}$ & 2.03992 & 0.02424 & 0.00010 & $-6.68464 \times 10^{-8}$ & $1.000^{*}$ & $\mathrm{Y}_{f i}$ & 20.05175 & 0.23201 & 0.00019 & $-9.60470 \times 10^{-7}$ & $1.000^{*}$ \\
\hline & $\mathrm{Y}_{f a}$ & 1.80540 & 0.01804 & $5.61862 \times 10^{-5}$ & $-6.77983 \times 10^{-8}$ & $1.000^{*}$ & $\mathrm{Y}_{f a}$ & 35.96916 & 0.24667 & $-7.73635 \times 10^{-5}$ & $-5.84612 \times 10^{-7}$ & $0.999^{*}$ \\
\hline \multirow[t]{2}{*}{ LOW } & $\mathrm{Y}_{f i}$ & 0.61288 & 0.00748 & $3.80401 \times 10^{-5}$ & $-5.27843 \times 10^{-8}$ & $1.000^{*}$ & $\mathrm{Y}_{f i}$ & 6.61302 & 0.08248 & 0.00026 & $-5.31902 \times 10^{-7}$ & $1.000^{*}$ \\
\hline & $\mathrm{Y}_{f a}$ & 0.56832 & 0.00673 & $1.93312 \times 10^{-5}$ & $-3.09698 \times 10^{-8}$ & $1.000^{*}$ & $\mathrm{Y}_{f a}$ & 8.30048 & 0.09660 & 0.00022 & $-4.20990 \times 10^{-7}$ & $0.999^{*}$ \\
\hline \multicolumn{13}{|c|}{ S3: $30 \%$ of the maize fields are planted randomly with GM maize } \\
\hline \multirow[t]{2}{*}{ HIGH } & $\overline{\mathrm{Y}_{f i}}$ & 1.59095 & 0.01886 & $8.16466 \times 10^{-5}$ & $-5.30107 \times 10^{-8}$ & $1.000^{*}$ & $\mathrm{Y}_{f i}$ & 48.22785 & 0.43280 & -0.00134 & $1.47881 \times 10^{-6}$ & $0.999^{*}$ \\
\hline & $\mathrm{Y}_{f a}$ & 1.44256 & 0.01500 & $4.89014 \times 10^{-5}$ & $-5.52564 \times 10^{-8}$ & $1.000^{*}$ & $\mathrm{Y}_{f a}$ & 59.47943 & 0.29073 & -0.00070 & $5.40126 \times 10^{-7}$ & $0.999^{*}$ \\
\hline \multirow[t]{2}{*}{ LOW } & $\mathrm{Y}_{f i}$ & 0.47940 & 0.00582 & $2.94543 \times 10^{-5}$ & $-4.09430 \times 10^{-8}$ & $1.000^{*}$ & $\mathrm{Y}_{f i}$ & 18.51812 & 0.22968 & 0.00012 & $-7.76147 \times 10^{-7}$ & $1.000^{*}$ \\
\hline & $\mathrm{Y}_{f a}$ & 0.45210 & 0.00540 & $1.72530 \times 10^{-5}$ & $-2.73998 \times 10^{-8}$ & $1.000^{*}$ & $\mathrm{Y}_{f a}$ & 17.94389 & 0.20382 & 0.00014 & $-5.54957 \times 10^{-7}$ & $0.999^{*}$ \\
\hline \multicolumn{13}{|c|}{ S3: 50\% of the maize fields are planted randomly with GM maize } \\
\hline \multirow[t]{2}{*}{ HIGH } & $\overline{\mathrm{Y}_{f i}}$ & 1.13442 & 0.01353 & $5.81770 \times 10^{-5}$ & $-3.75463 \times 10^{-8}$ & $1.000^{*}$ & $\overline{\mathrm{Y}_{f i}}$ & 66.97414 & 0.38723 & -0.00168 & $2.49021 \times 10^{-6}$ & $0.999^{*}$ \\
\hline & $\mathrm{Y}_{f a}$ & 1.05724 & 0.01134 & $4.03112 \times 10^{-5}$ & $-4.27832 \times 10^{-8}$ & $1.000^{*}$ & $\mathrm{Y}_{f a}$ & 71.80533 & 0.24834 & -0.00074 & $7.67198 \times 10^{-7}$ & $0.996^{*}$ \\
\hline \multirow[t]{2}{*}{ LOW } & $\mathrm{Y}_{f i}$ & 0.34721 & 0.00423 & $2.10382 \times 10^{-5}$ & $-2.91937 \times 10^{-8}$ & $1.000^{*}$ & $\mathrm{Y}_{f i}$ & 28.72244 & 0.32719 & -0.00030 & $-3.62191 \times 10^{-7}$ & $1.000^{*}$ \\
\hline & $\mathrm{Y}_{f a}$ & 0.33372 & 0.00397 & $1.47813 \times 10^{-5}$ & $-2.33481 \times 10^{-8}$ & $1.000^{*}$ & $\mathrm{Y}_{f a}$ & 24.54123 & 0.26310 & $-2.26625 \times 10^{-5}$ & $-5.12276 \times 10^{-7}$ & $0.997^{*}$ \\
\hline \multicolumn{13}{|c|}{ S3: $70 \%$ of the maize fields are planted randomly with GM maize } \\
\hline HIGH & $\overline{\mathrm{Y}_{f i}}$ & 0.67980 & 0.00815 & $3.42321 \times 10^{-5}$ & $-2.08981 \times 10^{-8}$ & $1.000^{*}$ & $\mathrm{Y}_{f i}$ & 78.63538 & 0.29101 & -0.01417 & $2.26529 \times 10^{-6}$ & $0.997^{*}$ \\
\hline & $\mathrm{Y}_{f a}$ & 0.65178 & 0.00728 & $2.76310 \times 10^{-5}$ & $-2.58807 \times 10^{-8}$ & $1.000^{*}$ & $\mathrm{Y}_{f a}$ & 78.90746 & 0.21728 & -0.00075 & $8.56772 \times 10^{-7}$ & $0.985^{*}$ \\
\hline LOW & $\mathrm{Y}_{f i}$ & 0.21164 & 0.00244 & $1.36606 \times 10^{-5}$ & $-2.00750 \times 10^{-8}$ & $1.000^{*}$ & $\mathrm{Y}_{f i}$ & 37.96300 & 0.37902 & -0.00065 & $9.67503 \times 10^{-8}$ & $0.999^{*}$ \\
\hline & $\mathrm{Y}_{f a}$ & 0.20681 & 0.00238 & $1.10397 \times 10^{-5}$ & $-1.75563 \times 10^{-8}$ & $1.000^{*}$ & $\mathrm{Y}_{f a}$ & 30.98907 & 0.29181 & $-7.61937 \times 10^{-5}$ & $-6.72623 \times 10^{-7}$ & $0.995^{*}$ \\
\hline & & & & & $10 \%$ of the maize & are cluste & d plar & GM maize & & & & \\
\hline HIGH & $\mathrm{Y}_{f i}$ & 0.25832 & 0.00293 & $2.69187 \times 10^{-5}$ & $2.44935 \times 10^{-8}$ & $1.000^{*}$ & $\mathrm{Y}_{f i}$ & 2.14994 & 0.02125 & $2.61065 \times 10^{-5}$ & $-3.54380 \times 10^{-8}$ & $1.000^{*}$ \\
\hline & $\mathrm{Y}_{f a}$ & 0.23758 & 0.00231 & $2.39174 \times 10^{-5}$ & $-2.17796 \times 10^{-10}$ & $1.000^{*}$ & $\mathrm{Y}_{f a}$ & 3.39373 & 0.02515 & $9.63735 \times 10^{-5}$ & $-1.92974 \times 10^{-7}$ & $1.000^{*}$ \\
\hline LOW & $\mathrm{Y}_{f i}$ & 0.07659 & 0.00057 & $1.20480 \times 10^{-5}$ & $-1.08062 \times 10^{-8}$ & $1.000^{*}$ & $\mathrm{Y}_{f i}$ & 0.93799 & 0.00948 & $5.44042 \times 10^{-5}$ & $-7.78600 \times 10^{-8}$ & $1.000^{*}$ \\
\hline & $\mathrm{Y}_{f a}$ & 0.07410 & 0.00055 & $9.85241 \times 10^{-6}$ & $-1.02981 \times 10^{-8}$ & $1.000^{*}$ & $\mathrm{Y}_{f a}$ & 0.80627 & 0.00997 & $3.97491 \times 10^{-5}$ & $-1.38241 \times 10^{-8}$ & $0.999^{*}$ \\
\hline & & & & & $30 \%$ of the maize & are cluste & d plar & GM maize & & & & \\
\hline HIGH & $\overline{\mathrm{Y}_{f i}}$ & 0.11026 & 0.00130 & $1.15159 \times 10^{-5}$ & $7.97760 \times 10^{-9}$ & $1.000^{*}$ & $\overline{\mathrm{Y}_{f i}}$ & 3.41158 & 0.03521 & $2.59185 \times 10^{-5}$ & $-3.87273 \times 10^{-8}$ & $1.000^{*}$ \\
\hline & $\mathrm{Y}_{f a}$ & 0.10284 & 0.00103 & $9.60331 \times 10^{-6}$ & $1.11272 \times 10^{-9}$ & $1.000^{*}$ & $\mathrm{Y}_{f a}$ & 5.36748 & 0.03158 & 0.00016 & $-3.04023 \times 10^{-7}$ & $1.000^{*}$ \\
\hline LOW & $\mathrm{Y}_{f i}$ & 0.03910 & 0.00028 & $5.51385 \times 10^{-6}$ & $-4.08635 \times 10^{-9}$ & $1.000^{*}$ & $\mathrm{Y}_{f i}$ & 1.56639 & 0.01702 & $7.08802 \times 10^{-5}$ & $-9.05966 \times 10^{-8}$ & $1.000^{*}$ \\
\hline & $\mathrm{Y}_{f a}$ & 0.03681 & 0.00029 & $4.55009 \times 10^{-6}$ & $-4.31751 \times 10^{-9}$ & $1.000^{*}$ & $\mathrm{Y}_{f a}$ & 1.15930 & 0.01441 & $7.71192 \times 10^{-5}$ & $-9.77009 \times 10^{-8}$ & $0.999^{*}$ \\
\hline & & & & S5: $10 \%$ of & farmers, who are se & randomly & ${ }_{N \mathrm{GM}}$ & on all their & e fields & & & \\
\hline HIGH & $\overline{\mathrm{Y}_{f i}}$ & 1.77424 & 0.01896 & 0.00011 & $-8.10836 \times 10^{-8}$ & $1.000^{*}$ & $\overline{Y_{f i}}$ & 15.44401 & 0.14755 & 0.00026 & $-7.21780 \times 10^{-7}$ & $1.000^{*}$ \\
\hline & $\mathrm{Y}_{f a}$ & 1.55073 & 0.01500 & $6.24773 \times 10^{-5}$ & $-7.75681 \times 10^{-8}$ & $1.000^{*}$ & $\mathrm{Y}_{f a}$ & 38.05536 & 0.20997 & -0.00010 & $-3.67368 \times 10^{-7}$ & $0.999^{*}$ \\
\hline LOW & $\mathrm{Y}_{f i}$ & 0.40879 & 0.00621 & $2.47307 \times 10^{-5}$ & $-1.70084 \times 10^{-8}$ & $1.000^{*}$ & $\mathrm{Y}_{f i}$ & 4.52979 & 0.05351 & 0.00017 & $-2.70968 \times 10^{-7}$ & $1.000^{*}$ \\
\hline & $\mathrm{Y}_{f a}$ & 0.39695 & 0.00498 & $1.63313 \times 10^{-5}$ & $-1.66321 \times 10^{-8}$ & $1.000^{*}$ & $\mathrm{Y}_{f a}$ & 9.21459 & 0.08865 & 0.00016 & $-3.54796 \times 10^{-7}$ & $0.999^{*}$ \\
\hline
\end{tabular}

* Significant at $P<0.001$ 
isolation perimeters were five to ten times lower when GM maize fields were grouped in one large cluster (S4), compared with a similar situation in which GM maize fields were randomly distributed (S3). This indicates that - even in regions with a high maize share - the clustering of GM maize fields may be, in theory, an effective strategy to facilitate the implementation of isolation perimeters and thus to guarantee the spatial separation of GM and non-GM crops. Islands of farmers growing GM maize on all their fields are a less attractive strategy compared with a large cluster.

Proportions of non-GM maize fields or farmers within perimeters increased with the width of the perimeter. By changing the isolation perimeter from $10 \mathrm{~m}$ to $50 \mathrm{~m}$ and to $200 \mathrm{~m}, 22.6 \pm 1.8,31.3 \pm 2.2$ and $65.8 \pm 3.3 \%$, respectively, of all non-GM maize fields in HIGH fell within the perimeters when $10 \%$ of the maize area was sown to GM maize randomly. Proportions changed to $52.7 \pm 2.3,65.6 \pm 2.5$ and $92.6 \pm 1.7 \%$, respectively, in the case where $30 \%$ of the maize area was planted to GM maize randomly, and to $3.8 \pm 1.6,5.1 \pm 2.1$ and $11.1 \pm 4.1 \%$ when $30 \%$ of GM maize was clustered in one cluster.

As soon as $10 \%$ of the maize area in HIGH is randomly planted with GM maize, more than $65.8 \pm 3.3 \%$ of the nonGM maize fields, involving $77.0 \pm 4.4 \%$ of all non-GM maize farmers, fall within a perimeter of $200 \mathrm{~m}$, which makes it very difficult to spatially isolate GM maize fields from nonGM ones. The clustering of GM maize fields is approximately eight times more efficient. Reducing the isolation perimeter to $10 \mathrm{~m}$ reduces the proportions of non-GM maize fields within perimeters the three times, whilst clusters continue to be much more efficient. An isolation perimeter of $200 \mathrm{~m}$ in LOW includes a similar proportion of non-GM maize fields within the perimeter as occurs in HIGH with an isolation perimeter of $25 \mathrm{~m}$.

The combination of GIS datasets with Monte Carlo simulations proved to be a valuable tool in estimating the feasibility of implementing isolation perimeters in real agricultural settings. Compared with studies that generated buffer zones around randomly selected maize fields (Dolezel et al., 2005 in Austria; Messéan et al., 2006 in France) or that classified maize fields into grid squares of $25 \times 25 \mathrm{~m}$ with a minimal measurable distance between two maize areas of $50 \mathrm{~m}$ (Sanvido et al., 2005 in Switzerland), this approach allows the testing of more diverse and flexible scenarios over a large number of simulation runs. Not only fields were considered in the calculations, but also farmers. Distance matrixes offer the possibility to simulate various scenarios with different GM maize shares and spatial distributions at the landscape level.

Since the feasibility of implementing isolation perimeters is largely affected by regional characteristics such as maize share and field distribution, the developed methodology may underpin a regional approach for the choice of appropriate coexistence measures. In regions where high maize shares hamper the implementation of isolation perimeters, one may rely on the clustering of GM maize fields on a larger scale. Growing GM maize in a limited number of farms decreases part of the advantage of clustering GM maize fields on a larger scale, but still offers a better solution than a random distribution. If isolation perimeters wider than $50 \mathrm{~m}$ or the clustering of GM maize fields continue to be difficult to implement in practice, the use of differences in sowing times or of pollen barriers may be considered on a case-by-case basis. In practice, however, any approach will only be workable when neighbouring farmers talk to each other in due time and make good arrangements prior to sowing. The GIS-based approach allows the provision of accurate information on distances between fields and on interactions with perimeters.

Further investigations are needed to refine the proposed approach, since it represents a 'worst-case' scenario. We assumed that it would not be possible to keep the adventitious GM content below the European threshold if a non-GM maize field lies within the isolation perimeter. Scientific literature on pollen flow and cross-fertilisation in maize, and ongoing research and modelling work indicate that in particular cases, this might not be true. Further research is also needed to quantify better the respective contributions of size, number and spatial distribution of maize fields on the feasibility of implementing isolation perimeters. Despite its conservativeness, our approach fulfils current administrative needs. It not only allows farmers to be informed if their fields fall within an isolation perimeter, but also to quantify how many fields may be prone to the interaction with GM maize fields, hence helping to budget some of the administrative, legal and financial consequences of co-existence at the landscape level. In most countries/regions, GM maize growers are supposed to pay a financial contribution into a fund in order to enable authorities to compensate for economic losses due to adventitious mixing, and to cover administrative, sampling and analytical detection costs. It is, therefore, crucial to know in advance the numbers of potential farmers and/or fields that may be affected by coexistence measures.

\section{REFERENCES}

Bannert M. (2006) Simulation of transgenic pollen dispersal by use of different grain colour maize, Ph.D. thesis, Swiss Federal Institute of Technology Zurich, Zurich, Switzerland.

EC (2003a) Commission Recommendation of 23 July 2003 on guidelines for the development of national strategies and best practices to ensure the coexistence of genetically modified crops with conventional and organic farming, Official J. Euro. Comm. L189, 36-47.

EC (2003b) Regulation (EC) 1829/2003 of the European Parliament and of the Council of 22 September 2003 on genetically modified food and feed, Official J. Euro. Comm. L268, 1-23.

EC (2006) Report on the implementation of national measures on the co-existence of genetically modified crops with conventional and organic farming.

Della Porta G., Ederle D., Bucchini L., Prandi M., Pozzi C., Verderio A. (2006) Gene flow between neighboring maize fields in the Po Valley: a fact-finding investigation regarding coexistence between conventional and non-conventional maize farming in the region of Lombardy, Italy. Report, Centro Documentazione Agrobiotechnologie, Milan, Italy.

Demeke T., Perry D.J., Scowcroft W.R. (2006) Adventitious presence of GMOs: scientific overview for Canadian grains, Can. J. Plant Sci. $86,1-23$. 
Devos Y., Reheul D., De Schrijver A. (2005) The co-existence between transgenic and non-transgenic maize in the European Union: a focus on pollen flow and cross-fertilization, Environ. Biosafety Res. $4,71-87$.

Devos Y., Reheul D., De Waele D., Van Speybroeck L., (accepted) The interplay between societal concerns and the regulatory frame on GM crops in the European Union, Environ. Biosafety Res.

Dolezel M., Pascher K., Grabherr G. (2005) Regionality as a key parameter for co-existence of genetically modified maize with conventional and organic maize, in: Messéan A. (Ed.), Proceedings of the 2nd International Conference on Co-existence between GM and non-GM based agricultural supply chains, Agropolis Productions, Montpellier, pp. 203-206.

Flannery M.-L., Meade C., Mullins E. (2005) Employing a composite gene-flow index to numerically quantify a crop's potential for gene flow: an Irish perspective, Environ. Biosafety Res. 4, 29-43.

Goggi A.S., Caragea P., Lopez-Sanchez H., Westgate M., Arritt R., Clark C. (2006) Statistical analysis of outcrossing between adjacent maize grain production fields, Field Crop Res. 99, 147-157.

Gustafson D.I., Brants I.O., Horak M.J., Remund K.M., Rosenbaum E.W., Soteres J.K. (2006) Empirical modeling of genetically modified maize grain production practices to achieve European Union labeling thresholds, Crop Sci. 46, 2133-2140.

Halsey M.E., Remund K.M., Davis C.A., Qualls M., Eppard P.J., Berberich S.A. (2005) Isolation of maize from pollen-mediated gene flow by time and distance, Crop Sci. 45, 2172-2185.

Marvier M., Van Acker R.C. (2005) Can crop transgenes be kept on a leash? Front. Ecol. Environ. 3, 99-106.

Messéan A., Angevin F., Gómez-Barbero M., Menrad K., RodríguezCerezo E. (2006) New case studies on the coexistence of GM and non-GM crops in European agriculture. Report, Joint Research Centre and Institute for Prospective Technological Studies, Seville, Spain.

Messeguer J., Peñas G., Ballester J., Bas M., Serra J., Salvia J., Palaudelmàs M., Melé E. (2006) Pollen-mediated gene flow in maize in real situations of coexistence, Plant Biotechnol. J. 4, 633645.

Pla M., La Paz J.-L., Peñas G., García N., Palaudelmàs M., Esteve T., Messeguer J., Melé E. (2006) Assessment of real-time PCR based methods for quantification of pollen-mediated gene flow from GM to conventional maize in a field study, Transgenic Res. 15, 219-228.

Sanvido O., Widmer F., Winzeler M., Streit B., Szerencsits E., Bigler F. (2005) An evaluation of measures to ensure agricultural coexistence of GM and non-GM crops in Switzerland, in: Messéan A. (Ed.), Proceedings of the 2nd International Conference on Coexistence between GM and non-GM based agricultural supply chains, Agropolis Productions, Montpellier, pp. 179-182.

Schiemann J. (2003) Co-existence of genetically modified crops with conventional and organic farming, Environ. Biosafety Res. 2, 213217.

Van De Wiel C.C.M., Lotz L.A.P. (2006) Outcrossing and coexistence of genetically modified with (genetically) unmodified crops: a case study of the situation in the Netherlands, Neth. J. Agr. Sci. 54, 1735 .

Weber W.E., Bringezu T., Broer I., Holz F., Eder J. (2007) Coexistence between GM and non-GM maize crops - tested in 2004 at the field scale level (Erprobungsanbau 2004), J. Agron. Crop. Sci. 193, 79-92.

Weekes R., Allnutt T., Boffey C., Morgan S., Bilton M., Daniels R., Henry C. (2007) A study of crop-to-crop gene flow using farm scale sites of fodder maize (Zea mays L.) in the UK, Transgenic Res., doi: 10.1007/s11248-006-9036-0. 